\title{
Domestic Violence during the COVID-19 Pandemic in Portugal
}

\author{
Ana Gama ${ }^{a, b}$ Ana Rita Pedroa,b Maria João Leote de Carvalhoc, d \\ Ana Esteves Guerreiro $^{\text {e, } f}$ Vera Duarte ${ }^{c, e} \quad$ Jorge Quintas ${ }^{f, g} \quad$ Andreia Matias $^{\text {h }}$ \\ Ines Keygnaert ${ }^{g}$ Sónia Dias ${ }^{a, b}$ \\ ${ }^{a}$ NOVA National School of Public Health, Public Health Research Centre, Universidade NOVA de Lisboa, Lisbon, \\ Portugal; ${ }^{b}$ Comprehensive Health Research Centre (CHRC), Lisbon, Portugal; ${ }^{c} \mathrm{CICS} . \mathrm{NOVA}$ - Interdisciplinary \\ Centre of Social Sciences, Lisbon, Portugal; ' NOVA School of Social Sciences and Humanities (NOVA FCSH), Lisbon,

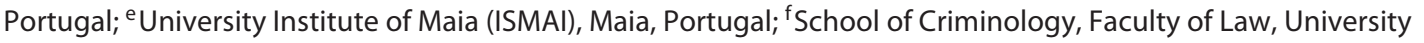 \\ of Porto, Porto, Portugal; ${ }^{9}$ CJS, Interdisciplinary Research Center on Crime, Justice and Security, Porto, Portugal; \\ hInstituto Universitário Egas Moniz, Almada, Portugal
}

\section{Keywords}

Domestic violence $\cdot$ COVID-19 pandemic $\cdot$ Help seeking $\cdot$

Public health · Online survey

\begin{abstract}
The measures implemented to combat the COVID-19 pandemic led populations to confinement at home, with increased risk of domestic violence due to extended shared time between victims and offenders. Evidence on domestic violence in times of pandemic is lacking. This study examines the occurrence of domestic violence, associated factors and help seeking during the COVID-19 pandemic. An online survey was conducted in Portugal between April and October 2020 by NOVA National School of Public Health. The survey was disseminated through partner networks, media, and institutions working within the scope of violence. Data were collected on the experience of domestic violence, and help seeking during the pandemic. In a total of 1,062 respondents, 146 (13.7\%) reported having suffered domestic violence during the pandemic, including psychological (13.0\%, $n=138)$, sexual $(1.0 \%, n=11)$, and physical $(0.9 \%, n=10)$ abuse. Overall, the lower the age, the more the reported do-
\end{abstract}

mestic violence. Also, a higher proportion of participants who perceived difficulties to make ends meet during the pandemic reported domestic violence. Differences between women and men and across educational levels on reported domestic violence were not statistically significant. Bivariate logistic analyses showed that, among women, reported domestic violence was more likely among those with up to secondary education compared to higher education. Most of the victims did not seek help (62.3\%), the main reasons being considering it unnecessary, that help would not change anything, and feeling embarrassed about what had happened. Only $4.3 \%$ of the victims sought police help. The most common reasons for not coming forward to form a complaint were considering the abuse was not severe and believing the police would not do anything. Our findings indicate that domestic violence during the COVID-19 pandemic was experienced by both sexes and across different age groups. There is a need for investing in specific support systems for victims of domestic violence to be applied to pandemic contexts, especially targeting those in more vulnerable situations and potentially underserved.

C 2021 The Author(s). Published by S. Karger AG, Base on behalf of NOVA National School of Public Health (c) 2021 The Author(s). Published by S. Karger AG, Basel on behalf of NOVA National School of Public Health This article is licensed under the Creative Commons AttributionNonCommercial-NoDerivatives 4.0 International License (CC BYNC-ND) (http://www.karger.com/Services/OpenAccessLicense) Usage and distribution for commercial purposes as well as any distribution of modified material requires written permission.
Ana Gama

NOVA National School of Public Health

Av. Padre Cruz

PT-1600-560 Lisbon (Portugal)

ana.gama@ensp.unl.pt 


\section{Violência doméstica em tempos de pandemia COVID-19 em Portugal}

\section{Palavras Chave}

Violência doméstica · Pandemia COVID-19 · Procura de ajuda $\cdot$ Saúde pública $\cdot$ Inquérito online

\section{Resumo}

As medidas implementadas para combater a pandemia COVID-19 levaram as populações ao confinamento em casa, com maior risco de violência doméstica devido ao prolongamento do tempo partilhado entre vítimas e agressores. A evidência sobre a violência doméstica em tempos de pandemia é limitada. Este estudo examina a ocorrência de violência doméstica, fatores associados e procura de ajuda durante a pandemia COVID-19. Um inquérito online foi realizado em Portugal em abril-outubro de 2020 pela Escola Nacional de Saúde Pública-NOVA. O inquérito foi divulgado em redes de parceiros, meios de comunicação e instituições que atuam no âmbito da violência. Foram recolhidos dados sobre a experiência de violência doméstica e procura de ajuda durante a pandemia. De um total de 1062 respondentes, $146(13,7 \%)$ relataram ter sofrido violência doméstica durante a pandemia, incluindo psicológica $(13,0 \%, n=$ $138)$, sexual $(1,0 \%, n=11)$ e física $(0,9 \%, n=10)$ No geral, quanto menor a idade, maior o reporte de violência doméstica. Também uma maior proporção de participantes que reportaram dificuldades financeiras durante a pandemia relatou violência doméstica. As diferenças entre mulheres e homens e entre os níveis educacionais no reporte de violência doméstica não foram estatisticamente significativas. Análises logísticas bivariadas mostraram que, nas mulheres, a violência doméstica foi mais reportada entre as que tinham até ensino secundário em comparação com ensino superior. A maioria das vítimas não procurou ajuda (62,3\%), sendo os principais motivos considerá-la desnecessária, que a ajuda não mudaria nada e sentir-se constrangida com o ocorrido. Apenas 4,3\% das vítimas procuraram ajuda policial. Os motivos mais comuns para não apresentar queixa foram considerar que o abuso não era grave e acreditar que a polícia não faria nada. Os resultados indicam que a violência doméstica durante a pandemia COVID-19 é transversal a ambos os sexos e a diferentes grupos etários. É necessário investir em sistemas de apoio específicos para vítimas de violência doméstica aplicados a contextos de pandemia, especialmente dire-

Domestic Violence during the COVID-19

Pandemic in Portugal cionados para grupos em situações mais vulneráveis e potencialmente desprotegidos.

(c) 2021 The Author(s) Published by S. Karger AG, Basel behalf of NOVA National School of Public Health

\section{Introduction}

The measures implemented to combat the COVID-19 pandemic altered the daily lives of all. As societies had to lockdown activities, businesses, and services, and populations were restricted to confinement at home, victims of domestic violence were kept closed in abusive relationships, with increased risk of violence [1, 2].

Domestic violence is a comprehensive term that includes many forms of abuse - physical, psychological, emotional, sexual, and financial - in an intimate or dependent family relationship $[3,4]$. Historically conceived as a problem of the private domain, domestic violence is currently recognized as a crime and represents a significant public health problem affecting the health and wellbeing of victims, their families, and communities [5-9]. It often escalates from threats and verbal assault to lifethreatening violence, and victims may suffer different forms of abuse and violence simultaneously [10]. Progressive scientific knowledge has shown that domestic violence is a gendered phenomenon, with differences in the magnitude, dynamics, and contexts underpinning domestic violence against women and against men [9]. Also, domestic violence is a quite transversal phenomenon across society, affecting all ages and any socioeconomic or cultural group, with complex and deeply entrenched underlying causes, and is often not officially reported $[2,11-14]$.

The domestic violence phenomenon during the COVID-19 pandemic is likely to follow patterns of previous pandemic events [15], where subsequent social isolation, economic instability, loss of income, and associated stress and family conflicts were strongly connected with increased risk of violence [16-18]. But in the current pandemic there is a legal imposition to confinement at home, thus the domestic violence prevalence may be higher than that reported in other catastrophe situations $[15,19,20]$. Reports of an increase in domestic violence during the pandemic have been emerging worldwide. Comparing April 2020 with the same period in the previous year, the WHO observed an increase of $60 \%$ of emergency calls from women subjected to intimate partner violence in European member states [21]. France report- 
Table 1. Characteristics of the participants and reported experience of domestic violence during the COVID-19 pandemic

\begin{tabular}{|c|c|c|c|c|}
\hline & \multirow[t]{2}{*}{ Total, $n(\%)$} & \multicolumn{3}{|c|}{$\begin{array}{l}\text { Experienced domestic violence during the } \\
\text { COVID-19 pandemic }\end{array}$} \\
\hline & & yes, $n(\%)$ & no, $n(\%)$ & $p$ value \\
\hline Total & $1,062(100)$ & $146(13.7)$ & $916(86.3)$ & \\
\hline \multicolumn{5}{|l|}{$\operatorname{Sex}(n=1,062)$} \\
\hline Female & $826(77.8)$ & $117(14.2)$ & $709(85.8)$ & 0.460 \\
\hline \multicolumn{5}{|l|}{ Age $(n=1,056)$} \\
\hline$<25$ years & $105(9.9)$ & $23(21.9)$ & $82(78.1)$ & 0.034 \\
\hline 25-39 years & $353(33.4)$ & $51(14.4)$ & $302(85.6)$ & \\
\hline $40-54$ years & $381(36.1)$ & $52(13.6)$ & $329(86.4)$ & \\
\hline 55-64 years & $153(14.5)$ & $16(10.5)$ & $137(89.5)$ & \\
\hline$\geq 65$ years & $64(6.1)$ & $4(6.3)$ & $60(93.8)$ & \\
\hline \multicolumn{5}{|c|}{ Perceived ability to make ends meet compared to the period before the COVID-19 pandemic $(n=992)$} \\
\hline More difficult/difficult as usual & $555(55.9)$ & $98(17.7)$ & $457(82.3)$ & 0.003 \\
\hline Easy as usual/easier & $437(44.1)$ & $48(11.0)$ & $389(89.0)$ & \\
\hline
\end{tabular}

ed a $30 \%$ increase in cases of domestic violence since March [22]. Germany and Spain also recorded increases in domestic violence reports and need for emergency shelter $[23,24]$. In contrast, an $8.6 \%$ decrease in complaints of domestic violence was registered in Portugal between January and September 2020 compared to the same period in 2019 , and a similar trend was observed in Italy [23, 25].

Documenting the early impact of the COVID-19 pandemic on domestic violence has been challenging due to under-reported cases and under-utilization of social services by victims [20]. There is a growing and immediate need to understand the occurrence of domestic violence during this pandemic. Such evidence is key to help develop effective strategies to prevent violence and assist victims. In the face of the lack of evidence on domestic violence in times of pandemic, the NOVA National School of Public Health in collaboration with Ghent University launched the research project "Violence in Intimate Relationships in Times of COVID-19: Gender Inequalities and (New) Contours of Domestic Violence?" This project aimed to better understand the impact of lockdown measures on domestic violence and shed light on help seeking by victims during this crisis. In this study we examine the occurrence of domestic violence, associated factors, and help seeking during the COVID-19 pandemic.

\section{Materials and Methods}

The project consisted of an online survey conducted between April and October 2020. The survey was disseminated through partner networks, digital social networks, social media, and community institutions working within the scope of violence. After clicking on the link of the survey, potential participants accessed information on the study and the consent form. Only respondents who gave informed consent were able to participate in the survey. The inclusion criteria were being $>16$ years old and living in Portugal.

Data were collected using a structured, closed-ended questionnaire administered through the Qualtrics software program. Among other questions, participants were asked about their sociodemographic characteristics, victimization in 3 forms of violence (psychological, physical, and sexual), and help seeking. The questionnaire was developed by Ghent University based on the UN-MENAMAIS Study questionnaire [26], drawn on a set of validated instruments [27-30]. Minor adaptations were made to the national context in terms of language and the response options to some questions (e.g., level of education). To ensure cross-country comparability, all proposed changes were agreed by both country research teams. The questionnaire was pretested among a convenience sample of individuals who met the inclusion criteria to ensure comprehensibility and solve operational errors.

Descriptive analysis was performed to analyze sociodemographic characteristics and domestic violence outcomes. Bivariate associations between sociodemographics and reported domestic violence, including psychological, physical, and sexual violence, were assessed using $\chi^{2}$ and Fisher's exact tests when appropriate. Bivariate logistic regression analyses stratified by sex were performed to estimate the crude odds ratios (OR) and 95\% CIs of fac-
Gama et al. 
Table 2. Reported experience of domestic violence during the COVID-19 pandemic and associated factors among women $(n=826)$

\begin{tabular}{|c|c|c|c|c|}
\hline & \multirow[t]{2}{*}{$\begin{array}{l}\text { Total women, } \\
n(\%)\end{array}$} & \multicolumn{3}{|c|}{$\begin{array}{l}\text { Experienced domestic violence during the } \\
\text { COVID-19 pandemic }\end{array}$} \\
\hline & & $n(\%)$ & crude OR $(95 \% \mathrm{CI})$ & $p$ value \\
\hline \multicolumn{5}{|l|}{ Age } \\
\hline$<25$ years & $84(10.2)$ & $18(21.4)$ & $2.73(0.75-10.0)$ & 0.129 \\
\hline 25-39 years & $301(36.7)$ & $41(13.6)$ & $1.58(0.46-5.40)$ & 0.469 \\
\hline $40-54$ years & $285(34.8)$ & $40(14.0)$ & $1.63(0.48-5.60)$ & 0.436 \\
\hline 55-64 years & $117(14.3)$ & $15(12.8)$ & $1.47(0.40-5.42)$ & 0.562 \\
\hline$\geq 65$ years & $33(4.0)$ & $3(9.1)$ & 1 & 1 \\
\hline \multicolumn{5}{|l|}{ Education } \\
\hline Up to secondary education & $132(16.2)$ & $28(21.2)$ & $1.80(1.12-2.89)$ & 0.015 \\
\hline Higher education & $684(83.8)$ & $89(13.0)$ & 1 & \\
\hline \multicolumn{5}{|c|}{ Ability to make ends meet compared to the period before the COVID-19 pandemic } \\
\hline More difficult/difficult as usual & $430(55.2)$ & $76(17.7)$ & $1.61(1.07-2.43)$ & 0.022 \\
\hline Easy as usual/easier & $349(44.8)$ & $41(11.7)$ & 1 & \\
\hline
\end{tabular}

Table 3. Reported experience of domestic violence during the COVID-19 pandemic and associated factors among men $(n=236)$

\begin{tabular}{|c|c|c|c|c|}
\hline & \multirow[t]{2}{*}{$\begin{array}{l}\text { Total men, } \\
n(\%)\end{array}$} & \multicolumn{3}{|c|}{$\begin{array}{l}\text { Experienced domestic violence during the } \\
\text { COVID-19 pandemic }\end{array}$} \\
\hline & & $n(\%)$ & crude OR $(95 \% \mathrm{CI})$ & $p$ value \\
\hline \multicolumn{5}{|l|}{ Age } \\
\hline$<25$ years & $21(8.9)$ & $5(23.8)$ & $9.37(1.01-87.28)$ & 0.049 \\
\hline 25-39 years & $52(22.0)$ & $10(19.2)$ & $7.14(0.87-58.82)$ & 0.068 \\
\hline $40-54$ years & $96(40.7)$ & $12(12.5)$ & $4.29(0.53-34.38)$ & 0.171 \\
\hline 55-64 years & $36(15.3)$ & $1(2.8)$ & $0.86(0.05-14.30)$ & 0.915 \\
\hline$\geq 65$ years & $31(13.1)$ & $1(3.2)$ & 1 & \\
\hline \multicolumn{5}{|l|}{ Education } \\
\hline Up to secondary education & $55(24.2)$ & $6(10.9)$ & $0.793(0.31-2.06)$ & 0.634 \\
\hline Higher education & $172(75.8)$ & $23(13.4)$ & 1 & \\
\hline \multicolumn{5}{|c|}{ Ability to make ends meet compared to the period before the COVID-19 pandemic } \\
\hline More difficult/difficult as usual & $125(58.7)$ & $22(17.6)$ & $2.47(1.01-6.07)$ & 0.049 \\
\hline Easy as usual/easier & $88(41.3)$ & $7(8.0)$ & 1 & \\
\hline
\end{tabular}

tors associated with reported domestic violence. A significance level $<0.05$ was used. Data analysis was performed using IBM-SPSS Statistics version 26.

\section{Results}

In total, 1,062 participants responded the online survey. Their characteristics are presented in Table 1.

Overall, 146 participants (13.7\%) reported having suffered domestic violence during the COVID-19 pandemic (Table 1). There was a trend of lower age associated with more domestic violence being reported. Also, a higher proportion of participants who perceived difficulties in making ends meet during the pandemic reported domestic violence (17.7\%). Differences in reported domestic violence between women and men and across educational levels were not statistically significant.

Bivariate logistic regression analyses stratified by sex showed that for women reported domestic violence was more likely among those with up to secondary education compared to higher education (Table 2). In both sexes, reported domestic violence remained more likely among those reporting difficulties to make ends meet during the 
Fig. 1. Reported psychological, physical, and sexual violence by sex.
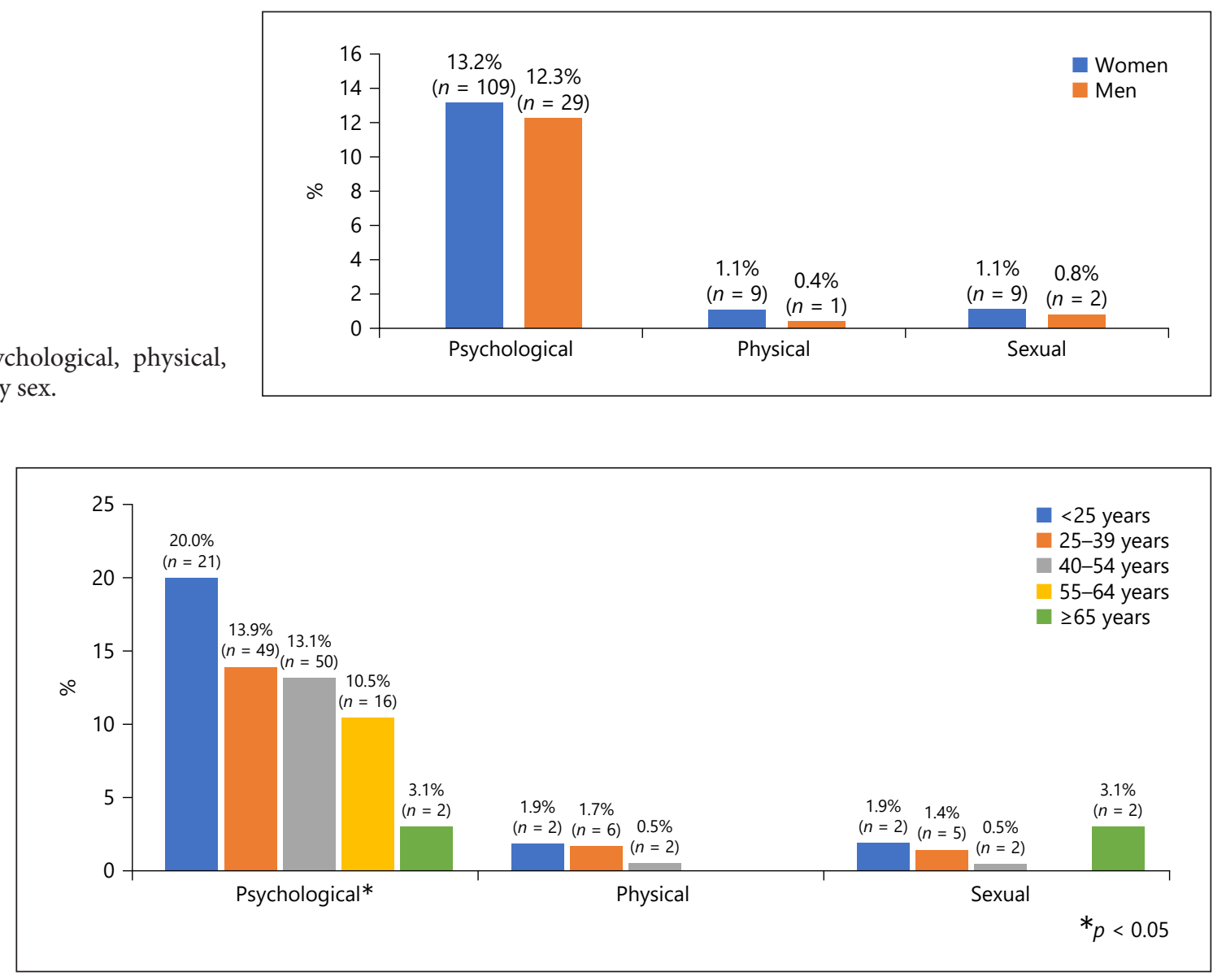

Fig. 2. Reported psychological, physical, and sexual violence by age group.

pandemic and was also higher among those of younger age (although not statistically significant among women; Tables 2, 3).

The perpetrator of the abuse was mostly a partner/expartner $(47.3 \%, n=69)$, but for some victims it was a parent/stepparent $(17.8 \%, n=26)$, a child/stepchild (8.9\%, $n=13)$, a sibling/stepsibling $(1.4 \%, n=2)$, or someone else the victim was currently living with $(2.7 \%, n=4) ; 32$ participants (21.9\%) did not report who the perpetrator was. Regarding the form of violence, a significant proportion of participants reported psychological $(13.0 \%, n=$ $138)$, sexual $(1.0 \%, n=11)$, and physical violence $(0.9 \%$, $n=10)$ during the pandemic. A total of 11 participants suffered concurrent forms of violence: psychological and physical (4 women and 1 man), psychological and sexual ( 2 women and 2 men), and psychological, physical, and sexual ( 2 women).

Women were more exposed to any form of violence than men, though differences were not statistically sig- nificant (Fig. 1). Younger participants ( $<25$ years old) reported the highest proportion of psychological and physical violence (Fig. 2). The older the participants, the less the reported psychological abuse. Nevertheless, among the elders ( $\geq 65$ years old), a high proportion reported sexual violence (3.1\%). Participants with up to secondary education reported particularly high rates of psychological violence during the pandemic (17.1\%; Fig. 3). Also, $1.6 \%$ of those with up to secondary education reported sexual abuse. Among participants with higher education, a significant proportion reported psychological and physical violence. Participants who perceived difficulties in making ends meet during the pandemic were more prone to suffer psychological violence and reported high rates of sexual and physical violence (Fig. 4).

Table 4 describes help seeking during the COVID-19 pandemic by the participants who experienced any form of violence $(n=146)$. Most of the victims did not seek help $(62.3 \%)$, and the main reasons were because they consid- 
Fig. 3. Reported psychological, physical, and sexual violence by educational level.
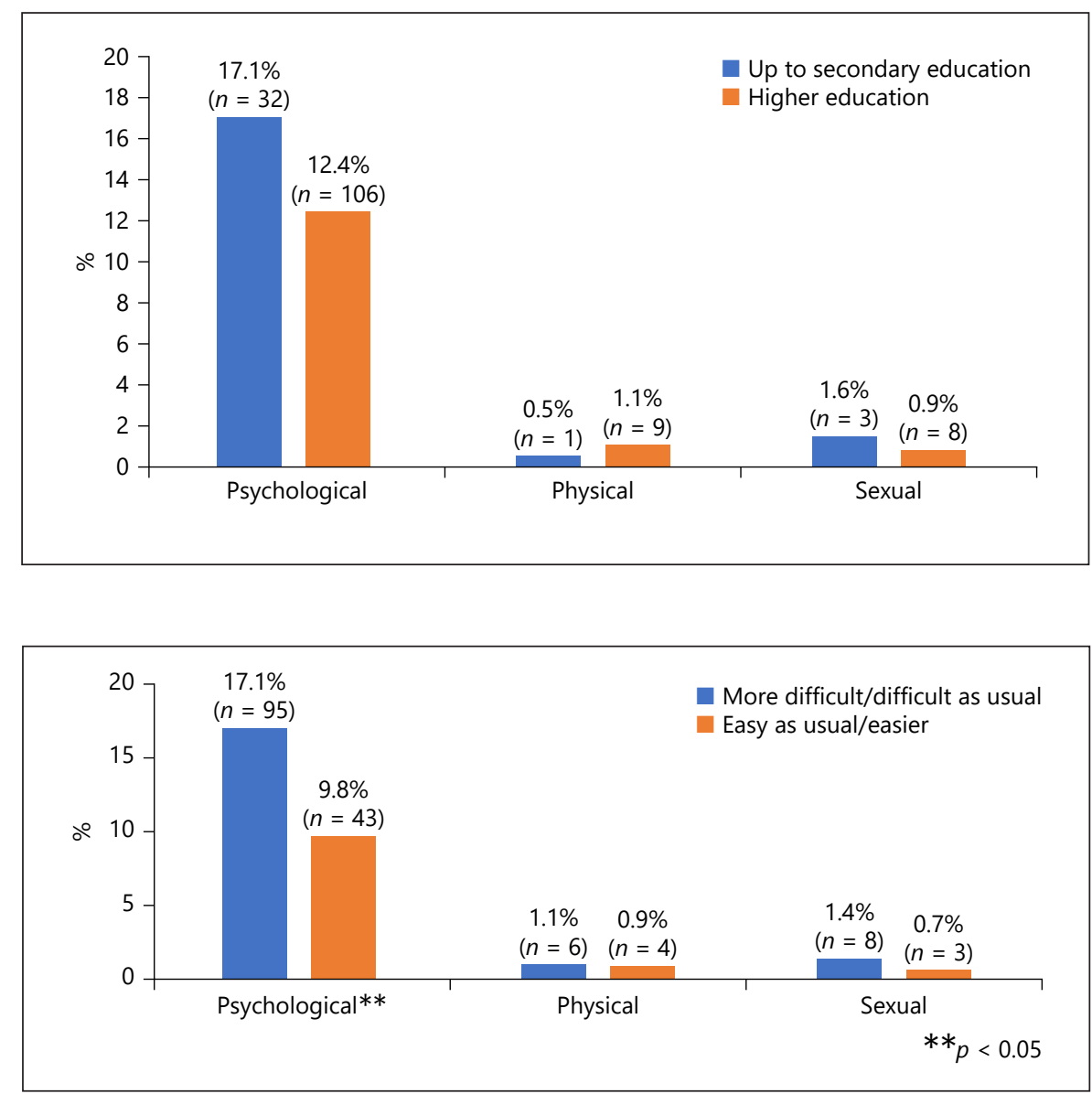

Fig. 4. Reported psychological, physical, and sexual violence by perceived ability to make ends meet compared to the period before COVID-19. ered it was not needed (32.2\%) and that help would not change anything (13.0\%). Other reasons included feeling embarrassed about what had happened (3.4\%), thinking they would not be believed or taken seriously (2.7\%), not wanting to stress the health care professionals even more in this crisis $(2.7 \%)$, not wanting the perpetrator to get in trouble $(2.7 \%)$, not wanting to bring a bad name to their own family (2.1\%), and financial or transportation limitations $(2.1 \%)$. Around $19 \%$ of the victims reported other reasons, although no specification was made.

Overall, 38 participants reported having sought professional help, mainly from mental health professionals (17.8\%), but also from a general practitioner (1.4\%) and a judicial institution (1.4\%), while 17 participants did not report if they had sought help. Only $4.3 \%$ of the victims sought police help $-2.6 \%$ went personally to the police department and $1.7 \%$ called the police. Around $88 \%$ stated they did not present any complaint to the police, and $6.9 \%$ did not complain but were unaware whether someone did. The main reason keeping victims from coming forward to form a complaint was not considering the abuse severe (54.1\%). Some victims also pointed out they believed the police would not do anything $(8.9 \%)$, that the person who committed the abuse was someone they knew (8.2\%), and feeling embarrassed about what had happened $(6.2 \%)$.

\section{Discussion}

This study provides evidence of domestic violence during the COVID-19 pandemic, in line with the literature suggesting a high occurrence of violence in times of crisis or disasters $[15,24]$. Domestic violence has strong implications for the health of the victims, including adverse mental health outcomes such as mood disorders and anxiety [31]. Importantly, in our study most of the victims did not officially report the abuse or seek help.

The findings indicate that domestic violence during the COVID-19 pandemic is transversal to both sexes and across different age groups. The high rates of reported domestic violence found against women (either psycho- 
Table 4. Help seeking during the COVID-19 pandemic

$n(\%)$

From whom did you seek help or advice after this? (multiple responses)

Did not seek help/advice

$91(62.3)$

A mental health practitioner (e.g., psychologist, psychiatrist, ...)

$26(17.8)$

A general practitioner

$2(1.4)$

A judicial institution

$2(1.4)$

A specialist (e.g., gynaecologist, urologist, ...)

$1(0.7)$

A helpline

$1(0.7)$

Other

$6(4.1)$

Which are the major reasons why you haven't sought help or advice from these people or services (so far)? (multiple responses)

I don't need help

I don't think that help would change anything

I feel embarrassed about what happened

$19(13.0)$

I think I will not be believed or taken seriously

$5(3.4)$

I don't want to stress the health care professionals even more in this crisis

$4(2.7)$

I don't want the person who did this to me to get in trouble

$4(2.7)$

$4(2.7)$

I don't want to bring a bad name to my family

$3(2.1)$

Due to financial or transportation limitations

$3(2.1)$

I don't trust anyone

$2(1.4)$

I don't know where to go

$1(0.7)$

Other reason

$27(18.5)$

Did you or somebody else tell the police about this? $(n=116)$

Yes, I went to the police department in person

$3(2.6)$

Yes, I called the police

$2(1.7)$

$1(0.9)$

No, but somebody else did it

$102(87.9)$

No, but I don't know if somebody else did

$8(6.9)$

Which are the major reasons why you haven't told the police (so far)? (multiple responses)

It was not severe enough

$79(54.1)$

The police would not do anything

$13(8.9)$

The person who did this to me is someone I know

$12(8.2)$

I feel embarrassed about what happened

$9(6.2)$

I feel partly responsible for what happened

$5(3.4)$

$5(3.4)$

The police would not believe me or take me seriously

$5(3.4)$

The person who did this to me would not get caught or get punished

$5(3.4)$

I don't feel safe with the police

$3(2.1)$

I don't know what would happen after I told the police

$2(1.4)$

I have had previous negative experiences with the police

$1(0.7)$

I don't want to stress the police officers even more in this crisis

$20(13.7)$

logical, physical, or sexual) extends the existing literature on the nature of this phenomenon, which is generally described as a gender-based crime where women are mostly victims $[2,14]$. Among female participants, domestic violence affected all age groups but varied with educational level, affecting disproportionately those with secondary education compared to higher education.

A significant proportion of victimized men, especially of psychological abuse, was also found in our study, which deserves attention. In this group domestic violence was independent of education but was significantly higher among younger individuals. While the concept of masculinity has been used to understand embodied practices and structural reinforcement of gender-based violence against women within patriarchal systems of power, little research has explored male victims' vulnerability and help seeking [32-34].

The findings indicate that the younger the participants, the more the reported domestic violence, in line with the literature [35]. In addition, a relevant finding is
Port J Public Health 2020;38(suppl 1):32-40 DOI: $10.1159 / 000514341$
Gama et al. 
that a particularly high proportion of elder participants reported sexual violence. Globally, there are limited official estimates of sexual abuse of older persons. There may be a risk that sexual abuse against this group is overlooked since, due to ageism, they may be seen as asexual, and thus sexual abuse may be considered unlikely to occur [36].

An association was found between perceived financial difficulties triggered by economic crisis during the pandemic and domestic violence, either among women or men. Research on the initial effects of the pandemic shows an aggravation of social inequalities, with increasing unemployment and loss of income that, in addition to isolation during the confinement of lockdown, have been drivers of domestic violence $[37,38]$.

In our study, the majority of the victims did not seek professional help or present a complaint to police authorities. Some of the most common reasons reported by participants for not seeking help are consistent with the literature, including playing down the significance of the abuse, feelings of shame and embarrassment, and sense of lack of support and distrust from the services, among others [38]. Seeking help from health services, community associations, or the police may have also been reduced in the face of the restrictive measures to combat the pandemic that impacted the office hours of many institutions.

The limitations of this study must be acknowledged. Due to the sampling procedure, results may not reflect the situation of the population in general. Volunteer bias cannot be excluded and, being an online study, it might have included particularly those with digital literacy. Social desirability bias potentially led to under-reporting of experiences of violence. Nevertheless, the anonymous online nature of this survey might have contributed to minimizing those effects. Overall, the burden of domestic violence could be under-represented. Given the relatively low numbers, which hindered further complex analyses, results must be treated with caution. The wide dissemination of the survey allowed a sample of 1,062 participants to be reached, with a high participation of respondents with higher education. Although the study design led to the inclusion of mainly highly educated groups, this can be considered a strength of the study as these groups are not frequently included in research on domestic violence $[6,35]$.

In conclusion, although progress has been made in efforts to prevent psychological, physical, and sexual violence, this study shows that there is a need for investment in specific support systems for victims of domestic violence to be applied to pandemic contexts, especially targeting those in more vulnerable situations, potentially underserved, and who do not access online platforms or have limited digital literacy. To our knowledge this is one of the largest community-based surveys conducted so far on domestic violence during the COVID-19 pandemic in Portugal. It provides insights to inform public policies regarding management mechanisms of domestic violence while examining the vulnerabilities of the system, which will be valuable should lockdown measures be repeated or re-instituted in the future.

\section{Statement of Ethics}

The study was approved by the Ethics Commission of the NOVA National School of Public Health (ref. CE/ENSP/ CREE/1/2020). The research conforms with the guidelines for human studies and was conducted ethically in accordance with the World Medical Association Declaration of Helsinki. Anonymity of participants and confidentiality of data were guaranteed. Informed consent was obtained from all participants.

\section{Conflict of Interest Statement}

The authors have no conflicts of interest to declare.

\section{Funding Sources}

This study was co-financed by the Foundation for Science and Technology, under the financing program "GENDER RESEARCH for COVID-19," with the following project partners: NOVA National School of Public Health (ENSP-NOVA), NOVA School of Social Sciences and Humanities (NOVA FCSH), University Institute of Maia (ISMAI), and School of Criminology, Faculty of Law, University of Porto.

\section{Author Contributions}

A.E.G., A.R.P., I.K., and S.D.: concept and design. A.E.G., A.R.P., M.J.L.d.C., A.E.G., V.D., J.Q., A.M., and S.D.: acquisition, analysis, or interpretation of data. A.E.G., A.R.P., and S.D.: drafting of the manuscript. A.E.G., A.R.P., A.M., M.J.L.d.C., A.E.G., V.D., J.Q., I.K., and S.D.: critical revision of the manuscript for important intellectual content. S.D. and A.E.G.: supervision.

References

1 Bradbury-Jones C, Isham L. The pandemic paradox: the consequences of COVID-19 on domestic violence. J Clin Nurs. 2020 Jul; 29(13-14):2047-9.

2 Evans ML, Lindauer M, Farrell ME. A pandemic within a pandemic: intimate partner violence during COVID-19. N Engl J Med. 2020 Dec;383(24):2302-4. 
3 Lourenço N, Carvalho MJ. Violência doméstica: conceito e âmbito: tipos e espaços de violência. Themis. 2001;II(3):95-121.

4 Gerino E, Caldarera AM, Curti L, Brustia P, Rollè L. Intimate partner violence in the golden age: systematic review of risk and protective factors. Front Psychol. 2018 Sep;9:1595.

5 Dobash R, Dobash R, Cavanagh K, Lewis R. Not an ordinary killer; just an ordinary guy: when male murder an intimate female partner. Violence Against Women. 2004 Jun; 10(6):577-605

6 Matias A, Gonçalves M, Soeiro C, Matos M. Intimate partner homicide: a meta-analysis of risk factors. Aggress Violent Behav. 2020;50: 101358.

7 Shuler C. Male victims of intimate partner violence in the United States: an examination of the review of literature through the critical theoretical perspective. Int J Crim Justice Sci. 2010;5(1):163-73.

8 Neves S. Violências de género na intimidade. Maia: Edições ISMAI; 2020.

9 Magalhães MJ. A violência nas relações de intimidade: um contributo para a definição de alguns conceitos. Lisboa: Centro de Documentação e Arquivo Feminista Elina Guimarães; 2005. [cited 2020 Dec 10], Available from https://www.cdocfeminista.org/wp-content/uploads/2013/05/ViolenciaConceitosMJM2005.pdf.

10 Center for Disease Control and Prevention. Preventing Intimate partner violence. Atlanta: Division of Violence Prevention. National Center for Injury Prevention and Control; 2018. Available from https://www.cdc.gov/ violenceprevention/pdf/ipv/IPV-factsheet_2020_508.pdf [cited 2020-12-10].

11 Dahlberg LL, Mercy JA. History of violence as a public health problem. Virtual Mentor. 2009 Feb;11(2):167-72.

12 Auderset D, Akre C, Barrense-Dias Y, Berchtold A, Jacot-Descombes C, Leeners B, et al. Profile of young victims of unwanted sexual experiences: a gender comparison using a Swiss National Survey. Sex Res Soc Policy. 2020;18(1):127-36.

13 Sartin R, Hansen D, Huss M. Domestic violence treatment response and recidivism: a review and implications for the study of family violence. Aggress Violent Behav. 2020;11(5): 425-40.

14 Krahé B, Berger A. Men and women as perpetrators and victims of sexual aggression in heterosexual and same-sex encounters: a study of first-year college students in Germany. Aggress Behav. 2013 Sep-Oct;39(5):391404.

15 Molyneaux R, Gibbs L, Bryant RA, Humphreys C, Hegarty K, Kellett C, et al. Interpersonal violence and mental health outcomes following disaster. BJPsych Open. 2019 Dec; 6(1):e1.
16 Lisboa M, Barroso Z, Patrício J, Leandro A. Violência e género: Inquérito Nacional sobre a Violência contra Mulheres e Homens. Lisboa: Comissão para a Cidadania e Igualdade de Género; 2009.

17 Campbell LM, Jones SJ. An innovative response to family violence after the canterbury earthquake events: canterbury family violence collaboration's achievements, successes, and challenges. Australas J Disaster Trauma Stud. 2016;20(2):89-100.

18 Chan KL, Zhang Y. Female victimization and intimate partner violence after the May 12, 2008, Sichuan earthquake. Violence Vict. 2011;26(3):364-76.

19 International Rescue Committee. Rapid assessment on gender and violence against women and girls in the Ebola outbreak in Beni, DRC. New York, NY: IRC; 2019. Available from: https://www.rescue.org/sites/default/files/document/3593/genderandgbvfindingsduringevdresponseindrc-final8march2019.pdf [cited 2020-12-10].

20 Kaukinen C. When stay-at-home orders leave victims unsafe at home: exploring the risk and consequences of intimate partner violence during the COVID-19 pandemic. Am J Crim Justice. 2020 Jun;45(4):1-12.

21 Mahase E. Covid-19: EU states report 60\% rise in emergency calls about domestic violence. BMJ. 2020 May;369:m1872.

22 Ertan D, El-Hage W, Thierrée S, Javelot H, Hingray C. COVID-19: urgency for distancing from domestic violence. Eur J Psychotraumatol. 2020 Sep;11(1):1800245.

23 Women UN. COVID-19 and ending violence against women and girls. New York (NY): The United Nations Entity for Gender Equality and the Empowerment of Women; 2020.[ [cited 2020 Dec 10]]. Available from: https:// www.unwomen.org/-/media/headquarters/ attachments/sections/library/publications/2020/issue-brief-covid-19-and-endingviolence-against-women-and-girls-en. pdf?la $=$ en\&vs $=5006$.

24 Graham-Harrison E, Giuffrida A, Smith H, Ford L. Lockdowns around the world bring rise in domestic violence. The Guardian. 2020; March 28. Available from: https://www. theguardian.com/society/2020/mar/28/lockdowns-world-rise-domestic-violence [cited 2020-12-10].

25 Portugal. Ministério da Administração Interna. Polícia de Segurança Pública. Comunicado de Imprensa: Violência doméstica: 24 de outubro de 2020. Lisboa: PSP; 2020. Available from: https://www.psp.pt/Pages/comunicados-imprensa.aspx [cited 2020-12-10].
26 Keygnaert I, Vandeviver C, Nisen L, De Schrijver L, Depraetere J, Nobels A, et al. Seksueel geweld in België: eerste representatieve prevalentiestudie naar de aard, omvang en impact van seksueel geweld in België. Science Connection. 2018;59:28-31.

27 Koss M, Abbey A, Campbell R, Cook S, Norris $\mathrm{J}$, Testa $\mathrm{M}$, et al. The sexual experiences short form victimization (SES-SFV). Tucson (AZ): University of Arizona; 2006.

28 Walters ML, Chen J, Breiding MJ. The National Intimate Partner and Sexual Violence Survey (NISVS): 2010 findings on victimization by sexual orientation. Atlanta (GA): $\mathrm{Na}-$ tional Center for Injury Prevention and Control. Centers for Disease Control and Prevention; 2013.

29 Krahé B, Berger A, Vanwesenbeeck I, Bianchi G, Chliaoutakis J, Fernández-Fuertes AA, et al. Prevalence and correlates of young people's sexual aggression perpetration and victimisation in 10 European countries: a multilevel analysis. Cult Health Sex. 2015;17(6): 682-99.

30 Keygnaert I, Dias SF, Degomme O, Devillé W, Kennedy P, Kováts A, et al. Sexual and gender-based violence in the European asylum and reception sector: a perpetuum mobile? Eur J Public Health. 2015 Feb;25(1):90-6.

31 El-Serag R, Thurston RC. Matters of the heart and mind: interpersonal violence and cardiovascular disease in women. J Am Heart Assoc. 2020 Feb;9(4):e015479.

32 Huntley AL, Potter L, Williamson E, Malpass A, Szilassy E, Feder G. Help-seeking by male victims of domestic violence and abuse (DVA): a systematic review and qualitative evidence synthesis. BMJ Open. 2019 Jun; 9(6): 021960

33 Machado A, Matos M. Homens vítimas na intimidade: análise metodológica dos estudos de prevalência. Psicol Soc. 2014;26(3):72636.

34 Depraetere J, Vandeviver C, Beken TV, Keygnaert I. Big boys don't cry: a critical interpretive synthesis of male sexual victimization. Trauma Violence Abuse. 2020 Dec;21(5): 991-1010.

35 Capaldi DM, Knoble NB, Shortt JW, Kim HK A systematic review of risk factors for intimate partner violence. Partn Abus. 2012 Apr; $3(2): 231-80$.

36 Malmedal W, Iversen MH, Kilvik A. Sexual abuse of older nursing home residents: a literature review. Nurs Res Pract. 2015;2015: 902515.

37 Martin A, Markhvida M, Hallegatte S, Walsh B. Socio-economic impacts of COVID-19 on household consumption and poverty. Econ Disaster Clim Chang. 2020 Jul;4(3):1-27.

38 Hardyns W, Keygnaert I, Ponnet K, Vandeviver C. Partner and domestic violence during the COVID-19 crisis. Free from Fear. Turin: UNICRI; 2020. p. 48-55. 